\title{
VENTILATOR-ASSOCIATED PNEUMONIA DUE TO MULTIDRUG- RESISTANT ACINETOBACTER BAUMANNII: INCIDENCE OF RISK FACTORS WITH IMPACT ON EARLY AND LATE MORTALITY
}

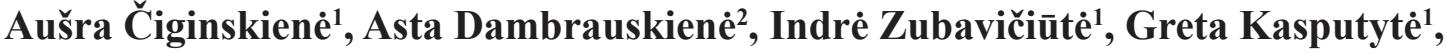 \\ Vidas Pilvinis ${ }^{1}$, Tomas Vanagas ${ }^{3}$, Dalia Adukauskien $\dot{e}^{1}$ \\ ${ }^{1}$ Department of Intensive Care, Medical Academy, Lithuanian University of Health Sciences, Kau- \\ nas, Lithuania, ${ }^{2}$ Infection Control Service, Medical Academy, Lithuanian University of Health \\ Sciences, Kaunas, Lithuania, ${ }^{3}$ Department of Surgery, Medical Academy, Lithuanian University of \\ Health Sciences, Kaunas, Lithuania
}

Keywords: A.baumannii, drug resistance, ventilatorassociated pneumonia (VAP), risk factors, mortality

\begin{abstract}
Summary
Background. This analysis is aimed to determine the incidence of risk factors for VAP, drug resistance of A.baumannii strains, 7-day (early) and 28-day (late) mortality, and association of risk factors for VAP with early and late mortality in multidrug-resistant (MDR) A.baumannii VAP patients cohort.

Materials and methods. Adult subjects with the first episode of MDR A.baumannii VAP during 2 years period were included. VAP was diagnosed using the 2005 ATS/IDSA criteria. Risk factors for VAP predicting early and late mortality were estimated using binary logistic regression analysis.

Results. The incidence of risk factors for VAP among 60 MDR A.baumannii VAP patients was: both continuous sedation and stress ulcer prophylaxis $-100 \%$, exposure to intravenous broad-spectrum antibiotics within the last 90 days $-98.3 \%$, current hospitalization $\geq 5$ days $-95.0 \%$, red blood cell transfusion $60.0 \%$, sepsis $-53.3 \%$, mechanical ventilation before VAP $>8$ days and SAPS II score $>50$ on ICU admission $-50.0 \%$. The resistance of A.baumannii strains to both piperacillin/tazobactam and ciprofloxacin was $100 \%$, to carbapenems, cephalosporins $95.0 \%$, to colistin $0 \%$. Early mortality it was estimated to be $28.3 \%$, late one $-55.0 \%$. The SOFA score $>12$ on ICU admission have predicted early (OR 7.5; 95\% CI $2.052-27.408, \mathrm{p}=0.002)$ and late (OR 4.089; $95 \%$ Cl 1.292-12.92, $\mathrm{p}=0.017$ ) mortality, $>3$ classes of
\end{abstract}

antibiotics used before the onset of VAP (OR 3.993; 95\% CI 1.050-15.193, $\mathrm{p}=0.042$ ) - late one.

Conclusions. It was estimated twice higher late versus early mortality, and marginal resistance of A.baumannii strains to piperacillin/tazobactam, carbapenems, cephalosporins and ciprofloxacin but colistin. Both early and late mortality was predicted by higher severity of illness by SOFA score on ICU admission, but only late one - by the treatment with $>3$ different classes of antibiotics before VAP onset.

\section{Introduction}

Over the recent decade, Acinetobacter baumannii (A.baumannii) has become the one of the most prevalent pathogens in nosocomial settings, responsible for $5-10 \%$ of nosocomial pneumonia cases in ICU patients [1-4]. The persistent increasing of multidrug resistance of A.baumannii strains has been recognized as one of the most challenging issues in modern medicine [3].

In the literature the severity of illness, invasive monitoring and treatment procedures, exposure to intravenous antibiotics, especially to carbapenems and cephalosporins, mechanical ventilation (MV), also prolonged hospital length of stay (LOS) are defined as the risk factors for ventilator-associated pneumonia (VAP) due to multidrug-resistant (MDR) A.baumannii strains [2,5-6]. Meanwhile, timeliness and appropriateness of antibacterial treatment are referred to be the one of the most important factors related to the outcomes of MDR A.baumannii pneumonia patients [1]. Due to the high level of antibacterial resistance of A.baumannii strains, the selection of appropriate treatment becomes complicated, so the broad-spectrum empirical antibiotic therapy use to be 
frequently prescribed. The broad-spectrum antibiotics use is closely related to the development of antibacterial resistance, thus why the careful selection of treatment strategy is crucial to prevent further growth of it. Antibacterial resistance of A.baumannii strains varies in different geographical regions, countries and hospitals, and it changes over time [3]. So, the knowledge about local epidemiology, the incidence of risk factors for VAP and their interrelation with mortality, as well as the assessment of the individual patient characteristics (disease severity, underlying condition, comorbidities) are important for clinicians to suspect and diagnose VAP also to start appropriate treatment more rapidly.

A recent retrospective similarly designed study conducted by our group have evaluated risk factors for VAP and mortality interrelation with resistance profiles of A.baumannii also have estimated independent risk factors for overall inhospital mortality in VAP due to MDR A.baumannii cohort [10]. The link between risk factors for VAP and 7-day (early) also 28-day (late) mortality has not been analysed until now. Our hypothesis was that some of the risk factors for VAP could be useful for early and late mortality prognosis in VAP patients.

The main objective of this study was to identify risk factors for VAP predicting early and late mortality in MDR A.baumannii VAP patients. Secondary objectives were to identify: (1) incidence of risk factors for it due to MDR A.baumannii, (2) drug resistance of A.baumannii strains, also (3) early and late mortality in this cohort.

\section{Materials and methods}

This analysis of retrospective cohort study [10] on VAP due to MDR A.baumannii was performed at the largest Lithuanian University hospital Kaunas Clinics over a 24 month. The study was approved by the Kaunas Regional Biomedical Research Ethics Committee (No BEC-MF-156). Inclusion criteria: (1) age $\geq 18$ years, (2) the first episode of VAP due to MDR A.baumannii.

If pneumonia has occurred later than $48 \mathrm{~h}$ after the onset of MV it was defined as ventilator-associated. 2005 ATS/ IDSA criteria were used to make the clinical diagnosis of VAP [8], and the EUCAST guidelines - for the identification of A.baumannii isolates and testing their antibacterial susceptibility [9]. A.baumannii isolates were defined as MDR when they were non-susceptible to at least one agent in three or more antibacterial categories, whereas XDR - when they were non-susceptible to at least one agent in all but two or fewer antimicrobial categories [10]. Sepsis-2 criteria were used to define sepsis status, SOFA and SAPS II scores - to assess the disease severity on ICU admission [11].

Data collected for each VAP case have included age, gender, type of admission (medical/surgical), risk factors for VAP (hospital LOS, MV and antibacterial treatment d. prior to MDR A.baumannii VAP diagnosis, disease severity on ICU admission, sepsis status, red blood cell (RBC) transfusion, surgery, reintubation, tracheostomy, renal replacement therapy (RRT), enteral nutrition (EN), sedation, proton pump inhibitors (PPI), and classes of antibiotics received before the onset of VAP), drug resistance of A.baumannii strains, and outcome (discharge or death) at day 7 and 28 after the onset of VAP due to MDR A.baumannii.

In order to evaluate the relation between risk factors for VAP and mortality, the patients were divided into the following subgroups: based on the medians of continuous variables (disease severity by SOFA, SAPS II scores, the duration of MV and antibacterial treatment prior to VAP due to MDR A.baumannii), also in case of binary variables - on the presence or absence of VAP risk factors (continuous sedation, stress ulcer prophylaxis, LOS $\geq 5 \mathrm{~d}$., reintubation, tracheostomy, RRT, RBC transfusion, EN).

Statistics. The variables were summarized as frequencies and percentage or medians and interquartile ranges. The normality of data was tested using the Shapiro-Wilk normality test. Mann-Whitney non-parametric, Pearson's chi-square, or two-tailed Fisher's exact tests were performed to detect the differences between groups as appropriate. All of the variables that were measured were subjected to univariable analysis. Binary logistic regression analysis was applied to identify the independent predictors of 7-day and 28-day mortality. In all analyses, two-sided $p$ values of $<0.05$ were considered to be statistically significant. Statistical analysis was carried out while using the Statistical Package for the Social Sciences SPSS, version 26 (SPSS, Chicago, IL).

\section{Results}

The data of 73 mechanically ventilated patients with tracheal aspirates that were positive for MDR A.baumannii were analyzed. Eight cases did not meet the diagnostic criteria for VAP; 5 cases were treated as A.baumannii colonization; therefore, 60 cases were included in the final analysis.

Data on demographics of study cohort have been reported previously [7]. MDR A.baumannii was more likely to cause late-onset VAP $(90.0 \%$ vs $10.0 \%, \mathrm{p}<0.034)$. Strains of MDR phenotype caused $13.3 \%$ and of extended drug-resistance (XDR) phenotype $-86.7 \%$ of all cases of A.baumannii VAP, $(p<0.001)$.

The incidence of risk factors for VAP was: $100 \%$ - stress ulcer prophylaxis with PPI and continuous sedation, 98.3\% - exposure to the intravenous broad-spectrum antibiotics within the last 90 days, $95.0 \%$ - present hospitalisation $\geq$ 5 days, $60.0 \%$ - RBC transfusion before VAP onset, 53.3 
$\%$ - sepsis, $50.0 \%$ - SAPS II score $>50$ on ICU admission and MV $>8$ days, $45.0 \%$ - antibacterial treatment $>13$ d., 43.3\% - SOFA score $>12$ on ICU admission, 38.3 $\%$ - surgery, $31.7 \%$ - reintubation, $31.7 \%$ - EN, $18.3 \%$ - RRT before VAP onset, 13.3 $\%$ - tracheostomy before VAP onset. The median duration of antibiotic therapy during present hospitalisation was $13 \mathrm{~d}$. (IQR 7-18). 88.3\% of the patients were treated with more than one class of antibiotics: $38.3 \%$ - with two, $21.7 \%$ - with four, $20.0 \%$ - with three classes of antibiotics. $86.7 \%$ of the patients received cephalosporins, $56.7 \%-$ penicillins \pm beta-lactamase inhibitors (BLI), 30.0\% - carbapenems, $10.0 \%$ - fluoroquinolones, $8.3 \%$ - macrolides, $5.0 \%$ - aminoglycosides, and 3.3\% - tetracyclines. All MDR A.baumannii strains were resistant to piperacillin/tazobactam and ciprofloxacin but sensitive to colistin. Fig. 1 presents more detailed data on antibacterial resistance of A.baumannii strains.

Early mortality was $28.3 \%$, whereas late $-55.0 \%$. Based on the medians of disease severity scores on ICU admission, patients were divided into the following subgroups: SOFA score $\leq 12$ and SOFA score $>12$; SAPS II score $\leq 50$ and SAPS II score $>50$. In univariable analysis both early and late mortality was found to be associated with SOFA and SAPS II scores; respectively, mortality in SOFA $>12$ vs SOFA $\leq 12$ group was $50 \%$ vs $11.8 \%(p=0.002)$, in SAPS II $>50$ vs SAPS II $\leq 50$ group $-43.3 \%$ vs $13.3 \%(\mathrm{p}=0.020)$. The need for RRT prior to VAP statistically significantly increased early mortality $(63.6 \%$ vs $20.4 \%, p=0.008)$, whereas the treatment with $>3$ antibiotic-class drugs - the late one $(76.5 \%$ vs $46.5 \%, p=0.046)$. No statistically significant associations between early also late mortality and other risk factors for VAP were detected. Detailed data are presented in Table 1.

The stepwise backward binary logistic regression was used to determine VAP risk factors independently predicting early and late mortality. The following VAP risk factors statistically significantly associated with early and late mortality in univariable analysis were included: disease severity score on ICU admission (SOFA $>12$, SAPS II $>50$ ), RRT in the analysis of predictors of early mortality group, and disease severity score on ICU admission (SOFA $>12$, SAPS II $>50$ ), $>3$ classes of antibiotics used prior to VAP onset in the late one. Detailed data on VAP risk factors independently predicting early and late mortality in patients with VAP due to MDR A.baumannii are presented in Table 2 .

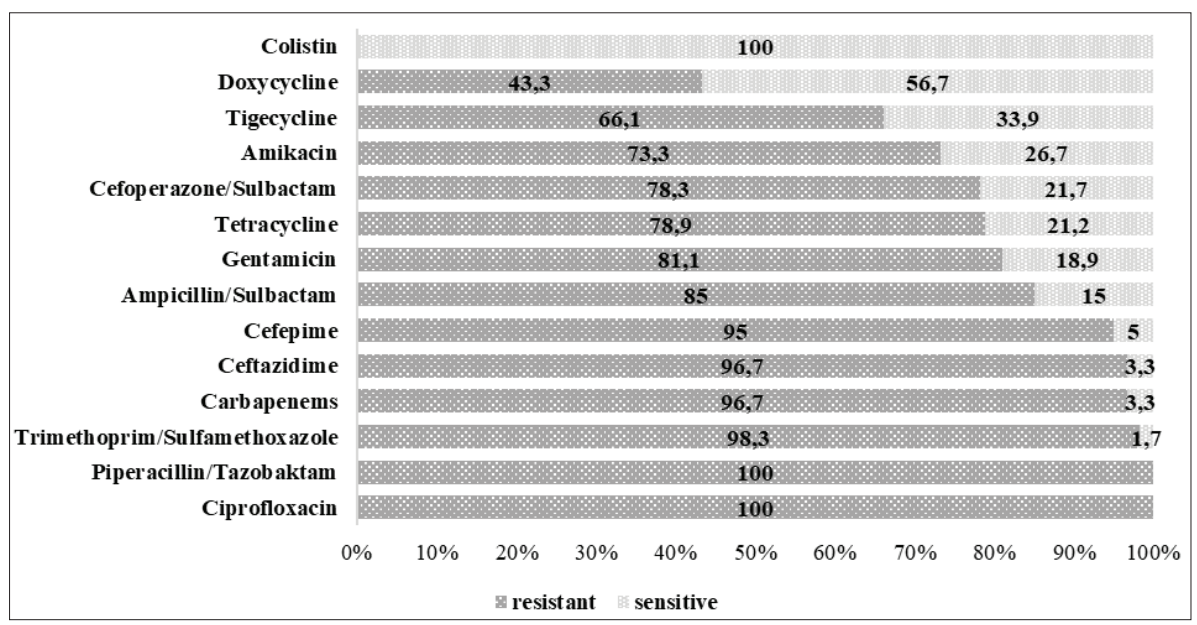

Fig 1. Antibacterial resistance of A.baumannii strains, \%

\section{Discussion}

The knowledge about the incidence of risk factors for VAP is useful for clinicians in assessing the individual risk of mechanically ventilated patients for the development of VAP, also in selecting management strategies to diminish the risk of VAP, while together, to influence the outcomes. The associations between invasive airway procedures, stress ulcer prophylaxis also $\mathrm{EN}$ and the risk of VAP has previously been reported [12-17]. Data of studies comparing the interrelation between tracheostomy and VAP are contraversal. Although Xie (2011) has found that tracheostomy predisposes the development of VAP, the study of Liu (2017) tracheostomy has determined as a protective factor [12-13]. The finding of Liu could be explained by more easier airway care and weaning from MV of tracheostomized patients. Reintubation and EN does increase the risk of aspiration also the acquisition of A.baumannii as a pathogen of VAP. It was already reflected in earlier study of Garnacho-Montero (2005) where A.baumannii has caused VAP in reintubated patients more often than other bacteria (46.34\% vs $17.5 \%$ p $<0.001$ ) [14]. Interestingly, the study of Ketter (2018) has determined that the human gastrointestinal tract has not the only function as a reservoir for MDR A.baumannii strains but also is linked to the development of drug resistance in them [15]. EN also create a favourable medium for bacterial growth and multiplication. On the other hand, EN is important for critically ill patients because 
it provides nutrition support and helps to prevent infectious complications, while the malnutrition leads to the weakening of the respiratory muscles, and complicates the weaning from MV.

The finding of previous studies on the relation between RBC transfusion and the development of VAP is also contradictory because it is difficult to confirm the causal link between RBC transfusion and VAP, as the risk of both RBC transfusion and nosocomial infections does increase with the prolonged LOS in ICU [16-17]. The earlier study of Shorr (2004) revealed the increased risk of VAP (OR 1.89), especially of late-onset one (OR 2.16) in transfused patients [16]. On the contrary, Engele (2017) didn't identify a relationship between RBC transfusion and the development of nosocomial (51\% of respiratory origin) infections [17]. The long-term treatment in the hospital was found to be related to the use broad spectrum antibiotic therapy, acquisition of MDR pathogens, and the risk of nosocomial infections. Moreover, the study of Garnacho-Montero has found a previous antibiotic use to be an independent predictor of acquisition of A.baumannii as a pathogen of VAP (OR 14, $\mathrm{p}<0.001$ ), though, the association of hospital LOS and VAP due to A.baumannii was observed only in univariable analysis [14]. In the small sample study of burn patients both the duration of the antibiotic therapy (OR 1.2,
Table 1. Associations of early and late mortality with the risk factors for VAP $V A P$ - ventilator associated pneumonia, IOR - interquartile range, ICU - intensive care unit, SAPS II — Simplified Acute Physiology Score, SOFA - Sequential Organ Failure Assessment, LOS - length of stay, MV mechanical ventilation, RRT - renal replacement therapy, $R B C$ - red blood cells, $E N$-enteral nutrition.

\begin{tabular}{|c|c|c|c|c|}
\hline VAP risk factors & Early mortality & p value & Late mortality & p value \\
\hline $\begin{array}{l}\text { SOFA score on ICU admission, } \mathrm{n}(\%) \text { : } \\
\cdot \quad \leq 12 \\
\cdot \quad>12\end{array}$ & $\begin{array}{c}4 / 34(11.8) \\
13 / 26(50.0)\end{array}$ & 0.002 & $\begin{array}{l}14 / 34(41.2) \\
19 / 26(73.1)\end{array}$ & 0.019 \\
\hline $\begin{array}{l}\text { SAPS II score on ICU admission, } \mathrm{n}(\%) \text { : } \\
\begin{array}{l}-\quad \leq 50 \\
\cdot \quad>50\end{array}\end{array}$ & $\begin{array}{c}4 / 30(13.3) \\
13 / 30(43.3)\end{array}$ & 0.020 & $\begin{array}{l}12 / 30(40.0) \\
21 / 30(70.0)\end{array}$ & 0.037 \\
\hline $\begin{array}{l}\text { Hospital LOS prior to VAP, } \mathrm{n}(\%) \text { : } \\
-\quad<5 \mathrm{~d} \text {. } \\
-\quad \geq 5 \mathrm{~d}\end{array}$ & $\begin{array}{c}0 / 3(0) \\
17 / 57(29.8)\end{array}$ & 0.551 & $\begin{array}{c}2 / 3(66.7) \\
31 / 57(54.4)\end{array}$ & 1.000 \\
\hline $\begin{array}{l}\text { MV d. prior to VAP, } \mathrm{n}(\%) \\
-\quad \leq 8 \mathrm{~d} \\
-\quad>8 \mathrm{~d}\end{array}$ & $\begin{array}{l}9 / 30(30.0) \\
8 / 30(26.7)\end{array}$ & 1.000 & $\begin{array}{l}18 / 30(60.0) \\
15 / 30(50.0)\end{array}$ & 0.604 \\
\hline $\begin{array}{l}\text { Antibacterial treatment prior to VAP, n }(\%) \text { : } \\
\text { - } \quad \leq 13 \mathrm{~d} . \\
-\quad>13 \mathrm{~d} .\end{array}$ & $\begin{array}{c}7 / 33(21.2) \\
10 / 27(37.0)\end{array}$ & 0.251 & $\begin{array}{l}15 / 33(45.5) \\
18 / 27(66.7)\end{array}$ & 0.123 \\
\hline $\begin{array}{l}\text { Sepsis prior to VAP, } \mathrm{n}(\%) \\
\text { - Yes } \\
\text { - } \quad \text { No }\end{array}$ & $\begin{array}{c}12 / 32(37.5) \\
5 / 28(17.9)\end{array}$ & 0.150 & $\begin{array}{c}19 / 32(59.4) \\
14 / 28(50)\end{array}$ & 0.604 \\
\hline $\begin{array}{l}\text { Reintubation prior to VAP, } \mathrm{n}(\%) \text { : } \\
\text { - Yes } \\
\text { - } \quad \text { No }\end{array}$ & $\begin{array}{c}6 / 19(31.6) \\
11 / 41(26.8)\end{array}$ & 0.763 & $\begin{array}{l}10 / 19(52.6) \\
23 / 41(56.1)\end{array}$ & 1.000 \\
\hline $\begin{array}{l}\text { Surgery prior to VAP, } \mathrm{n}(\%) \text { : } \\
\text { - Yes } \\
\text { - } \quad \text { No }\end{array}$ & $\begin{array}{l}8 / 23(34.8) \\
9 / 37(24.3) \\
\end{array}$ & 0.396 & $\begin{array}{l}14 / 23(60.9) \\
19 / 37(51.4)\end{array}$ & 0.595 \\
\hline $\begin{array}{l}\text { Tracheostomy prior to VAP, } \mathrm{n}(\%) \text { : } \\
\text { - Yes } \\
\text { - } \quad \text { No }\end{array}$ & $\begin{array}{c}4 / 8(50) \\
13 / 52(25)\end{array}$ & 0.206 & $\begin{array}{c}6 / 8(75.0) \\
27 / 52(51.9)\end{array}$ & 0.276 \\
\hline $\begin{array}{l}\text { RRT prior to VAP, } \mathrm{n}(\%) \text { : } \\
\text { - } \quad \text { Yes } \\
\text { - } \quad \text { No }\end{array}$ & $\begin{array}{c}7 / 11(63.6) \\
10 / 49(20.4)\end{array}$ & 0.008 & $\begin{array}{c}8 / 11(72.7) \\
25 / 49(51.0)\end{array}$ & 0.315 \\
\hline $\begin{array}{l}\text { RBC transfusion prior to VAP, } \mathrm{n}(\%) \text { : } \\
\text { - Yes } \\
\text { - } \quad \text { No }\end{array}$ & $\begin{array}{c}13 / 36(36.1) \\
4 / 24(16.7)\end{array}$ & 0.146 & $\begin{array}{l}22 / 36(61.1) \\
11 / 24(45.8)\end{array}$ & 0.295 \\
\hline $\begin{array}{l}\text { EN prior to VAP, n }(\%) \text { : } \\
\text { - Yes } \\
\text { - } \quad \text { No }\end{array}$ & $\begin{array}{c}5 / 19(26.3) \\
12 / 41(29.3)\end{array}$ & 1.000 & $\begin{array}{l}12 / 19(63.2) \\
21 / 41(51.2)\end{array}$ & 0.419 \\
\hline 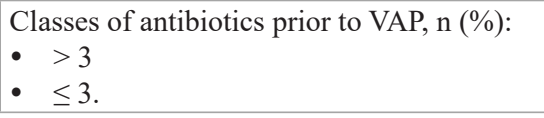 & $\begin{array}{l}8 / 17(47.1) \\
9 / 43(20.9)\end{array}$ & 0.059 & $\begin{array}{l}13 / 17(76.5) \\
20 / 43(46.5)\end{array}$ & 0.046 \\
\hline
\end{tabular}

Table 2. Risk factors for VAP independently predicting early and late mortality in patients with VAP due to MDR A.baumannii

$V A P$ - ventilator associated pneumonia, d. - days, OR - odds ratio, CI - confidence interval, SOFA - Sequential Organ Failure Assessment.

\begin{tabular}{|l|l|l|l|l|}
\hline \multirow{2}{*}{ Risk factor for VAP } & \multicolumn{3}{|c|}{ Type of mortality } \\
\cline { 2 - 5 } & \multicolumn{2}{|c|}{ Early (0-7 d.) mortality } & \multicolumn{1}{c|}{ Late (7-28 d.) mortality } \\
\cline { 2 - 5 } & OR (95\% CI) & p-value & OR (95\% CI) & p-value \\
\hline SOFA score $>12$ before VAP & $7.500(2.052-27.408)$ & 0.002 & $4.089(1.292-12.920)$ & 0.017 \\
\hline $\begin{array}{l}3 \text { classes of antibiotics used } \\
\text { before VAP }\end{array}$ & & $3.993(1.050-15.193)$ & 0.042 \\
\hline
\end{tabular}


$\mathrm{p}<0.05)$ and the number of antibacterial classes used (OR 2.5, $\mathrm{p}<0.05$ ) were found to be predictors of MDR A.baumannii infection [18]. Inchai (2015) have found that treatment with carbapenems has increased the risk of A.baumannii of each phenotypes of resistance (MDR, XDR, and PDR) [6]. The most prevalent risk factors for VAP in our analysis we have found to be continuous sedation, stress ulcer prophylaxis with PPI, exposure to the intravenous broad-spectrum antibiotics within the last 90 days (cephalosporins $-86.7 \%$, penicillins with BLI $-56.7 \%$, carbapenems $-30.0 \%$ ), current hospitalization $>5$ days, and $\mathrm{RBC}$ transfusion before VAP onset. These findings emphasize the importance of restrictive prescription of long-term sedative, gastric acid suppressive agents, also more responsible use of RBC transfusions in purpose to prevent VAP due to MDR A.baumannii. The tracheal colonisation preventive strategies (silver-impregnated tubes, subglottic suction, and oral decontamination), the early initiation of EN along with monitoring of possible delayed gastric emptying should be considered in MV patients. Overuse of multiple antibiotics should be avoided in clinical practice.

Recent VAP guidelines emphasize the role of regular generation and dissemination of local hospital antibiograms and empiric antibiotic regimens based upon the local distribution of pathogens associated with VAP and their antibacterial susceptibilities [5]. However, data on the resistance of A.baumannii strains actualy causing VAP in different geographical regions are insufficient. We have found marginal resistance of A.baumannii strains to piperacillin/tazobactam, ciprofloxacin, carbapenems, and cephalosporins, but colistin. Interesting data on antibacterial resistance of bacteria belonging to Acinetobacter calcoaceticus-Acinetobacter baumannii $(A c b)$ complex (mostly A.baumannii; $42.9 \%$ pneumonia cases) were presented in a long-term large-scale ( 259 centres) SENTRY study [3]. This study found none of the tested antibiotics to be able to inhibit the growth of all bacteria belonging to $A c b$ complex. On all continents, they were most susceptible to colistin (from $93.9 \%$ in Europe to $98.1 \%$ in Latin America) and minocycline (from $70.1 \%$ in Europe to 91.1\% in Latin America). The limited susceptibility to carbapenems was observed worldwide, and the susceptibility to meropenem (from $35.6 \%$ in Europe to $59.7 \%$ in North America) was slightly lower than to imipenem (from 39.4\% in Europe to $63.9 \%$ in North America). The susceptibility to ampicillin-sulbactam ranged from $21.6 \%$ in Latin America to $54.7 \%$ in North America. Strains isolated from patients with pneumonia have been found to be less susceptible to carbapenems, minocycline, and colistin in comparison with strains isolated from blood. Moreover, pneumonia was more often caused by $A c b$ complex bacteria of XDR phenotype
(63.7\%). Resistance of A.baumannii strains to carbapenems and ampicillin/sulbactam observed higher in our analysis than in SENTRY study might be explained by methodological differences: we have analysed selected cases of VAP due to A.baumannii of MDR phenotype, and most of they were of XDR phenotype, as colleagues have studied strains of all kinds of sensitivity.

VAP is characterised by high overall in-hospital mortality up to $70 \%$ in the case of MDR and XDR A.baumannii [19]. In our analysis, the early mortality rate was found to be almost twice higher (28.3\%) than reported in Choi's (2016) study $(15 \%)$ [20]. This difference could be attributed to the fact that the treatment with colistin to which all tested A.baumannii strains were sensitive became available in our hospital only since March 2015, however in Choi's study all enrolled patients have been treated with colistin for at least 3 days. The late mortality in our cohort was $55 \%$ similarly to the previous researches in this field [19]. Both early and late mortality was predicted by higher severity of illness by SOFA score on ICU admission, but only late one - by the treatment with $>3$ different classes of antibiotics before VAP onset. Our findings are in line with previous studies: Choi identified the severity of illness (APACHE II score) as the prognostic factor for early mortality, Inchai and Tsioutis (SAPS II) - for a late one [6,19-20].

Advantages and limitations of the study. The main advantage of this study is the fact that this is, to our knowledge, the first study analysing the incidence of risk factors for VAP and their predictive relation with early and late mortality. The limitations of our study are limited sample size and single-centre retrospective design. Additionally, the incidence of other important VAP risk factors (disease severity score on VAP onset, the presence of ARDS) and their relation to mortality has been not analysed, as the analysis of patients' data on VAP onset is the goal of our other ongoing extended study. The larger multicenter studies would be relevant.

\section{Conclusions}

Continuous sedation, stress ulcer prophylaxis with PPI, current hospitalisation $\geq 5$ days, treatment with broadspectrum antibiotics in preceding 90 days, and RBC transfusion were found to be the most prevalent risk factors for VAP due to MDR A.baumannii. Overall late mortality was found to be $55 \%$ as twice of early one. Both early and late mortality were predicted by SOFA score $>12$ on ICU admission, but late one - by treatment with $>3$ classes of antibiotics before the onset of VAP due to MDR A.baumannii. Almost all strains of A.baumannii were resistant to piperacillin/tazobactam, ciprofloxacin, carbapenems and cephalosporins, 
and none to colistin. Estimated twice higher late versus early mortality testifies about the aggressive nature of MDR A.baumannii in VAP. By outlook of our study, there is a clue to clinicians to increase a preventive alert and provide avoidance of risk factors for MDR A.baumannii (pathogen of VAP) as early as possible in purpose to start specific antimicrobial treatment and enable to predict high mortality more effectively. Thus recommendation for empirical use of colistin in VAP of suspected MDR A.baumannii is rational.

Declaration of interest statement. The authors report no conflicts of interest.

\section{References}

1. Vazquez Guillamet C, Kollef MH. Acinetobacter pneumonia: Improving outcomes with early identification and appropriate therapy. Clinical Infectious Diseases 2018;67(9):1455-62. https://doi.org/10.1093/cid/ciy375

2. Bassetti M, Righi E, Vena A, Graziano E, Russo A, Peghin M. Risk stratification and treatment of ICU-acquired pneumonia caused by multidrug-resistant/extensively drug-resistant/ pandrug-resistant bacteria. Current opinion in critical care 2018;24(5):385-93.

https://doi.org/10.1097/MCC.0000000000000534

3. Gales AC, Seifert H, Gur D, Castanheira M, Jones RN, Sader HS. Antimicrobial susceptibility of Acinetobacter calcoaceticus-Acinetobacter baumannii complex and Stenotrophomonas maltophilia clinical isolates: results from the SENTRY antimicrobial surveillance program (1997-2016). Open forum infectious diseases 2019; 6:S34-S46.

https://doi.org/10.1093/ofid/ofy293

4. Kempf M, Rolain JM. Emergence of resistance to carbapenems in Acinetobacter baumannii in Europe: clinical impact and therapeutic options. International Journal of Antimicrobial Agents 2012;39(2):105-14.

https://doi.org/10.1016/j.ijantimicag.2011.10.004

5. Kalil AC, Metersky ML, Klompas M, Muscedere J, Sweeney DA, Palmer LB, et al. Management of adults with hospital-acquired and ventilator-associated pneumonia: 2016 clinical practice guidelines by the Infectious Diseases Society of America and the American Thoracic Society. Clinical Infectious Diseases 2016;63(5):e61-111.

https://doi.org/10.1093/cid/ciw353

6. Inchai J, Liwsrisakun C, Theerakittikul T, Chaiwarith R, Khositsakulchai W, Pothirat C. Meanwhile, timeliness and appropriateness of antibacterial treatment are referred to be one of the most important factors related to outcomes of MDR A.baumannii pneumonia patients. Journal of Infection and Chemotherapy. 2015;21(8):570-4. https://doi.org/10.1016/j.jiac.2015.04.010

7. Čiginskienè A, Dambrauskienè A, Rello J, Adukauskienè A. Ventilator-associated pneumonia due to drug-resistant Acinetobacter baumannii: risk factors and mortality relation with resistance profiles, and independent predictors of in-hospital mortality. Medicina 2019; 55(2):1-13.

https://doi.org/10.3390/medicina55020049

8. American Thoracic Society, Infectious Diseases Society of America. Guidelines for the management of adults with hospital-acquired, ventilator-associated, and healthcare-associated pneumonia. American Journal of Respiratory and Critical care Medicine 2005;171(4):388.

https://doi.org/10.1164/rccm.200405-644ST

9. European Committee on Antimicrobial Susceptibility Testing (EUCAST). EUCAST breakpoints tables for interpretation of MICs and zone diametres, Version 2.0. 2015 [cited 2019 September 24]. Available from: http://www.eucast.org/fileadmin/src/media/PDFs/EUCAST_files/Breakpoint_tables/ Breakpoint_table_v_2.0_120221.pdf

10. Magiorakos AP, Srinivasan A, Carey RB, Carmeli Y, Falagas ME, Giske CG, et al. Multidrug-resistant, extensively drug-resistant and pandrug-resistant bacteria: an international expert proposal for interim standard definitions for acquired resistance. Clinical Microbiology and Infection 2012;18(3):268-81.

https://doi.org/10.1111/j.1469-0691.2011.03570.x

11. Campaign SS, Dellinger RP, Levy MM, Rhodes A, Annane $\mathrm{D}$, Gerlach $\mathrm{H}$, et al. International guidelines for management of severe sepsis and septic shock: 2012. Crit Care Med. 201;41(2):580-637.

12. Xie DS, Xiong W, Lai RP, Liu L, Gan XM, Wang XH, et al. Ventilator-associated pneumonia in intensive care units in $\mathrm{Hu}-$ bei Province, China: a multicentre prospective cohort survey. Journal of Hospital Infection 2011;78(4):284-8.

https://doi.org/10.1016/j.jhin.2011.03.009

13. Liu Y, Di Y, Fu S. Risk factors for ventilator-associated pneumonia among patients undergoing major oncological surgery for head and neck cancer. Frontiers of medicine 2017;11(2):239-46. https://doi.org/10.1007/s11684-017-0509-8

14. Garnacho-Montero J, Ortiz-Leyba C, Fernández-Hinojosa E, Aldabó-Pallás T, Cayuela A, Marquez-Vácaro JA, et al. Acinetobacter baumannii ventilator-associated pneumonia: epidemiological and clinical findings. Intensive Care Medicine 2005;31(5):649-55.

https://doi.org/10.1007/s00134-005-2598-0

15. Ketter PM, Yu JJ, Guentzel MN, May HC, Gupta R, Eppinger $\mathrm{M}$, Klose KE, et al. Acinetobacter baumannii gastrointestinal colonization is facilitated by secretory IgA which is reductively dissociated by bacterial thioredoxin A. MBio. 2018;9(4):e01298-18.

https://doi.org/10.1128/mBio.01298-18

16. Shorr AF, Duh MS, Kelly KM, Kollef MH. Red blood cell transfusion and ventilator-associated pneumonia: a potential link? Critical Care Medicine 2004;32(3):666-74. https://doi.org/10.1097/01.CCM.0000114810.30477.C3

17. Engele LJ, Straat M, van Rooijen IH, de Vooght KM, Cremer OL, Schultz MJ, et al. Transfusion of platelets, but not of 
red blood cells, is independently associated with nosocomial infections in the critically ill. Annals of Intensive Care. 2016;6(1):67.

https://doi.org/10.1186/s13613-016-0173-1

18. Yeong EK, Huang WL. Risk factors for multidrug-resistant Acinetobacter baumannii infections in a mass burn casualty incident. J Burn Care Res. 2019;pii:irz092. https://doi.org/10.1093/jbcr/irz092

19. Tsioutis C, Kritsotakis EI, Karageorgos SA, Stratakou S, Psarologakis C, Kokkini S, et al. Clinical epidemiology, treatment and prognostic factors of extensively drug-resistant Acinetobacter baumannii ventilator-associated pneumonia in critically ill patients. International Journal of Antimicrobial Agents 2016;48(5):492-7.

https://doi.org/10.1016/j.ijantimicag.2016.07.007

20. Choi IS, Lee YJ, Wi YM, Kwan BS, Jung KH, Hong WP, Kim JM. Predictors of mortality in patients with extensively drug-resistant Acinetobacter baumannii pneumonia receiving colistin therapy. International Journal of Antimicrobial Agents 2016;48(2):175-80.

https://doi.org/10.1016/j.ijantimicag.2016.05.011

\section{DAUGINIO ATSPARUMO ANTIBIOTIKAMS ACINETOBACTER BAUMANNII SUKELTA \\ VENTILIACINE் PNEUMONIJA: RIZIKOS VEIKSNIŲ PAPLITIMAS IR JU ITAKA ANKSTYVAJAM BEI VÉLYVAJAM MIRŠTAMUMUI}

A. Čiginskienė, A. Dambrauskienė, I. Zubavičiūtė, G. Kasputytė, V. Pilvinis, T. Vanagas, D. Adukauskienė

Raktažodžiai: A.baumannii, atsparumas antibiotikams, ventiliacinè pneumonija, rizikos veiksniai, mirštamumas.

Santrauka

Tikslas. Nustatyti ventiliacinès pneumonijos (VP) rizikos veiksnių paplitimą tarp dauginio atsparumo antibiotikams (DAA) A.baumannii sukeltos VP pacientų, detalų A.baumannii padermių atsparumą antibiotikams, $7 \mathrm{~d}$. (ankstyvaji) bei $28 \mathrm{~d}$. (vèlyvaji) jų mirštamumą bei VP rizikos veiksnių gebą prognozuoti ankstyvaji bei vẻlyvajị mirštamumą šioje pacientų kohortoje.

Darbo metodika. Retrospektyvi dvejų metų visų suaugusiųjų DAA A.baumannii VP (pirmas epizodas) pacientų ligos istorijų duomenų analizè. VP kliniškai diagnozuota pagal 2005 ATS/IDSA kriterijus. VP rizikos veiksniai, prognozuojantys mirštamumą, nustatyti atliekant dvinarès logistinès regresijos analizę.

Rezulatatai. VP rizikos veiksnių paplitimas 60 DAA A.baumannii VAP pacientų imtyje: nuolatinè sedacija ir stresinių opų profilaktika - 100\%, gydymas antibiotikais per pastarąsias $90 \mathrm{~d}$. $-98,3 \%$, dabartinè hospitalizacija $\geq 5$ d. $-95,0 \%$, eritrocitur masès transfuzija $-60 \%$, sepsis $-53,3 \%$, mechaninès ventiliacijos iki VP trukmè $>8 \mathrm{~d}$. ir SAPS II skalès įvertis $>50$ hospitalizuojant į ITS - 50,0\%. Visos A.baumannii padermès buvo atsparios piperacilinui/tazobaktamui ir ciprofloksacinui, $>95 \%$ - karbapenemams ir cefalosporinams , $0 \%$-kolistinui. Ankstyvasis mirštamumas siekè $28,3 \%$, vèlyvasis $-55,0 \%$. SOFA skalès įvertis $>12$ hospitalizuojant i ITS prognozavo ankstyvajji (ŠS 7,5; 95\% PI 2,052-27,408, $\mathrm{p}=0,002$ ) ir vėlyvaji (GS 4,089; 95\% Pl 1,292-12,92, p=0,017) mirštamumą, o gydymas $>3$ klasių antibiotikais iki VP pradžios (GS 3,993; 95\% PI 1,050-15,193, p=0,042) - tik vèlyvaji.

Išvados. Sunkesnè pacientų būklè pagal SOFA skalę hospitalizuojant ị ITS prognozavo tiek ankstyvajị, tiek ir vèlyvajị mirštamumą, o gydymas $>3$ klasių antibiotikais iki VP pradžios - tik vèlyvajji. Du kartus už ankstyvajị didesnis vèlyvasis mirštamumas nurodo agresyvią DAA A.baumannii VP eigą, todèl, VP sukèlèju ịtariant būtent A.baumannii, turètų būti svarstoma empirinio gydymo kolistinu galimybè.

Adresas susirašinèti: ausraciginskiene@yahoo.com

Gauta 2019-12-13 